\title{
SCIENTIFIC DATA栔
}

OPEN Author Correction: A data set of \section{inland lake catchment boundaries for the Qiangtang Plateau}

\section{Denghua Yan ${ }^{1}$, Meng $\mathrm{Li}^{1,2}$, Wuxia Bi $\mathbb{1}^{1,3}$, Baisha Weng ${ }^{1}$, Tianling Oin ${ }^{1}$, Jianwei Wang ${ }^{1}$ \& Pierre $\mathrm{Do}^{2}$}

Correction to: Scientific Data https://doi.org/10.1038/s41597-019-0066-x, published online 16 May 2019

Following publication of this Data Descriptor, it was found that the Normalized Difference Water Index (NDWI) threshold was incorrectly stated in the text. In all instances where the NDWI threshold is stated as 1.5 the actual value used was 0.15 .

In addition to the above, it was found that the blue overlay used in Figure 1 to indicate the presence of a river incorrectly intersected the inset image in the lower right.

These errors have been corrected in both the HTML and PDF versions of this Data Descriptor.

(c) Open Access This article is licensed under a Creative Commons Attribution 4.0 International License, which permits use, sharing, adaptation, distribution and reproduction in any medium or format, as long as you give appropriate credit to the original author(s) and the source, provide a link to the Creative Commons license, and indicate if changes were made. The images or other third party material in this article are included in the article's Creative Commons license, unless indicated otherwise in a credit line to the material. If material is not included in the article's Creative Commons license and your intended use is not permitted by statutory regulation or exceeds the permitted use, you will need to obtain permission directly from the copyright holder. To view a copy of this license, visit http://creativecommons.org/licenses/by/4.0/.

(C) The Author(s) 2019
${ }^{1}$ State Key Laboratory of Simulation and Regulation of Water Cycle in River Basin, China Institute of Water Resources and Hydropower Research (IWHR), Beijing, 100038, China. ${ }^{2}$ Institute of Water Resources and Hydrology Department of Hydraulic Engineering, Tsinghua University, Beijing, 100084, China. ${ }^{3}$ College of Hydrology and Water Resources, Hohai University, Nanjing, 210098, China. Correspondence and requests for materials should be addressed to B.W. (email:wengbs@iwhr.com) 